\title{
Resilience of tourism activity in times of the Covid-19 pandemic
}

\section{Resiliencia de la actividad turística en época de pandemia de Covid-19}

\author{
CAMELO-AVEDOY, José Octavio †*, GARCÍA-MONDRAGÓN, Leonardo and JACOBO- \\ GARRAFA, Dagoberto
}

Universidad Autónoma de Nayarit, Mexico.

ID $1^{\text {st }}$ Author: José Octavio, Camelo-Avedoy / ORC ID: 0000-0002-5722-3032, Researcher ID Thomson: H-3981-2018, CVU CONACYT ID: 99469

ID $1^{\text {st }}$ Coauthor: Leonardo, García-Mondragón / CVU CONACYT ID: 515507

ID $2^{\text {nd }}$ Coauthor: Dagoberto, Jacobo-Garrafa / CVU CONACYT ID: 287997

DOI: $10.35429 /$ EJRP.2020.11.6.1.17

Received July 10, 2020; Accepted December 30, 2020

\begin{abstract}
The pandemic that humanity is experiencing has generated a series of modifications in socio-economic life, social rituals, habits, among others; infection detected in December 2019, but spread massively in the first months of 2020. Tourism is an activity that has been severely affected, as the tourist is a mobility agent, and it is precisely to the mobility of people a strategy to contain the contagion of the Sars-Cov-2 virus. The objective of this document is to carry out an analysis of the context under which tourist activity has been affected by the Covid-19 pandemic; as well as, expose the resilience process that said activity has had in recent months. Research carried out from secondary sources, such as reports and publications of international organizations, official data, specialized agencies on passenger cars and the monitoring of the pandemic; A mixed theoretical framework is used, with economic concepts and categories, other from the study of tourism and some epidemiological. The result makes it possible to make visible, in a timely manner, what the resilience strategies of the tourism sector have been, taking five countries as references.
\end{abstract}

Turism, Economy, Covid-19, Resilience strategies

\begin{abstract}
Resumen
La pandemia que vive la humanidad ha generado una serie de modificaciones en la vida socio-económica, rituales sociales, hábitos, entre otros; infección dada a conocer en diciembre de 2019, pero difundida masivamente en los primeros meses de año 2020. El turismo es una actividad que se ha visto severamente afectada, al ser el turista un agente de movilidad, y es precisamente el impedir la movilidad de personas una estrategia de contención del contagio del virus Sars-Cov-2. El presente documento tiene como objetivo realizar un análisis del contexto bajo el cual se ha visto afectada la actividad turística por la pandemia de Covid-19; así como, exponer el proceso de resiliencia que dicha actividad ha tenido en los últimos meses. Investigación realizada a partir de fuentes secundarias, como informes y publicaciones de organismos internaciones, datos oficiales, agencias especializadas sobre turismos y el seguimiento de la pandemia; se maneja un marco teórico mixto, con elementos y categorías económicas, propias del estudio del turismo y algunas epidemiológicas. El resultado, permite hacer visible, de manera puntual, cuales han sido las estrategias de resiliencia del sector turístico, tomando a cinco países como referentes.
\end{abstract}

Turismo, Economía, Covid-19, estrategias de resiliencia

Citation: CAMELO-AVEDOY, José Octavio, GARCÍA-MONDRAGÓN, Leonardo and JACOBO-GARRAFA, Dagoberto. Resilience of tourism activity in times of the Covid-19 pandemic. ECORFAN Journal-Republic of Peru. 2020. 6-11:1-17.

\footnotetext{
* Correspondence to Author (email: ocameloa@uan.edu.mx)

$\dagger$ Researcher contributing first author.
} 


\section{Introduction}

In recent months, much has been said about the necessary changes that must be made to carry out the economic reactivation in all the countries that have been in quarantine and with measures to restrict mobility; Regarding tourism, the World Tourism Organization (2020) reported by the end of April that $100 \%$ of the tourist destinations in the world had imposed partial or total restriction measures, as a strategy to control the pandemic, so those Countries that were the first to initiate a stoppage of activities have gradually been reactivating their economic activities, including tourism.

In the present analysis, multiple proposals for tourist reactivation have been collected and the main measures found for the prevention and control of contagions in the tourist destinations that begin to operate have been identified; Based on this, a theoretical analysis of said proposals is carried out to identify the guidelines in the public policies implemented and proposed by different organizations focused on the economic reactivation of tourism; From this, the potentialities with which it is expected to be the guidelines of the new normality in tourism practice are identified, the adjustments that are projected will be necessary for its correct management and the general guidelines that will determine the new tourism practice in the short and medium term, contrasting with the projections made by some entities of the sector.

The theoretical framework used is mixed, exposing categories and concepts of economy, tourism and epidemiology. The objective is to present in a timely manner the main strategies for reactivating tourist activity that have been implemented by five countries, namely: China, Italy, Spain, the United States (EU) and Mexico. Research carried out with a heavy load of secondary sources, for obvious reasons, obtaining information from international organizations, specialized agencies, official institutions, official data, among others.
The document is structured by a first section entitled Theoretical Framework, where the categories and concepts used in the research are exposed; a second item is named Contextual Framework, which develops a presentation of the conditions under which tourist activity participates in the current pandemic; later, the third title is presented, Pandemics seen in cycles or waves of contagion, which indicates the behavior of other pandemics in the past; A fourth section is called -gradual reactivation of tourismwhich sets out the adaptations and new care criteria that were taken or modified to start activating tourism again; A next section shows how the five countries mentioned reactivated tourism activity; finally the conclusions are reached.

\section{Theoretical framework}

The economy is a science that studies the resources, production and distribution, starting from the market, that covers a social need. However, there are several definitions of economics that are considered classical; in this sense, there is Samuelson's definition, who defines it as "The study of the way in which societies use scarce resources to produce valuable goods and distribute it among different individuals." For his part, for Marx "it is a scientific discipline that analyzes the relations of production that occur within society." As well as these definitions, there are many others, but there is an elementary coincidence, regardless of whether it is based on scarce resources or a social need, which by itself marks an ideological difference in its construction.

From this, it follows that economic activity or dynamics, according to Heiler (1970 [1937]), "In physics the theory of motion is called dynamics. Transferring that concept to economic life, it is called dynamic economy. The economy in its movement. The economy is by nature, dynamic, that is, it already has in its foundations the causes of continuous variation, that is, movement, since its foundations: population, needs, techniques, etc. They are subject to continuous variations" (p.178). 
The economy, in its complexity of relationships, and being dynamic, presupposes that in this movement it has periods of greater activity and less activity; in those with the greatest activity it can be pointed out that economic activity is expanding; but, following the consideration of the approach that it is dynamic, there are economic moments of reduction of its dynamics. In studies by $\mathrm{N}$. Kondrátiev, he details that there are moments of expansion and contraction of economic activity.

Various theorists have studied these conjunctures that began to be analyzed by said author, although it is worth noting that Karl Marx already mentioned them since $3 / 4$ of the 1800s, in his work Capital. "But for Kondratiev, long waves were only half of the cycle: long rising and falling waves. The cycle is made up of the two waves" (Sandoval, 2008). Although there is a theoretical current of economists who study cycles, the truth is that there is no coincidence in their duration; Marx, Kondrátiev and Shumpeter handle cycles, in their writings, but with different duration.

As previously mentioned, when there is an economic activity, it may have a reduction, in long cycles it would be the downward wave; in order to establish a period of ascent or increase in activity, it is necessary to reactivate the economy; that is to say, that production, once it has decreased, begins to increase again, without, necessarily, there being major changes in the productive orientation of the country or region. It is said that the economy is re-activated. For the Side of the Republic of Colombia (2020) "It is called economic reactivation to the process through which it is sought to make the economy of a country or a certain place take good directions after having submerged in a crisis that affects the majority of the population. " (n/n).

Thus, the economic dynamics has its concrete expression in regions, since in the macroeconomic agglomerate the detection of the concrete is blurred.

It is the region, the dimension of study that allows observing the specific behavior of the production of merchandise, whatever the production orientation, and the sum of the production of the different regions, the agglomerated macroeconomic behavior.
Seen in this way, "the region understood as the physical space that, from a certain criterion, generates elements of homogeneity of production in the face of its regional counterpart that marks a heterogeneity with respect to the first, under the selected criterion of study. From the above, the region exists under the comparison, of an element, between the dissipation of the coined element as a homogenizing criterion, with respect to the emergence of differentiated elements. But, when speaking of social production, this refers then to the social valuation of production "(Camelo \& Rodríguez, 2018, p. 19), in the same sense Villa (2003) points out" the region cannot be conceived in itself itself. That is to say, the features, whether of homogeneity or heterogeneity, of a region where an infinity of vertical and horizontal relationships are linked are identifiable only if there is an opposite that has different features, or the same features, but quantitatively different from the region with the one that is compared "(p. 23). The region, then, is a social-historical process that determines the conditions for the valorization of production through the heterogeneity of its contiguous regional peer. "The region seen as the consequence of an economic-historical-social conformation, leads to culture, norms, values, among other aspects of identification of a region, it can be considered, from the political economy, that its origin is taken as a cause of the process gestated to establish the general conditions of capital accumulation of said region, of the extraction of the resources of the territory, of a process of social production" (Camelo, 2014, p. 31)

In the context of the different productive orientations within the regions, there are socalled tourist-oriented regions, those that make tourism their predominant activity in their economic dynamics. There are different meanings of tourism, due to the diversification of said activity, from: countryside, sun and beach, ecological, space, cyber-tourism (which no longer adheres to the classical principles of the concept of tourism) and more are emerging every day. But the general concept can be built from its origin, according to De la Torre (1997) the word tourism is derived from the roots tour and turn that come from the Latin, either from the noun tornus ("lathe") or from the verb tornare ("to turn", in vulgar Latin), whose connotation would be synonymous with "circular trip". 
But tourism has been conceived from very different perspectives, the following quote from Camelo, Rodríguez \& Rodríguez (2020) states "A good part of the content of the following definitions are expressed by authors such as: Schullern, Glückmann, Morgenroth, Bormann, Stradner and Troisi among others, who were part of the -Berlinian school- in the period from 1911 to 1939 , that is, before the First and Second World War. The first author to define tourism from an economic perspective was Hermann von Schullern zu Schrattehofen (1911 in Muñoz, 1992) Tourism is the set of all those processes, especially economic ones, that start arrivals, stays and departures of tourists to and from a certain community, region or state and who are directly related to them. For Glucksmann (1930, in Muñoz, 1992), an expiration of the space carried out by individuals who access a locality where they do not have their residence". According to Morgenroth, (1929, in Fuentes, 2016) tourism is an activity that leads the traffic of people who leave their usual place of residence to another place and there to satisfy needs of various kinds. Borman, (1930, in Cortés \& Muñoz, 2016) defines tourism as -The set of trips whose object is pleasure or commercial, professional or other similar reasons and during which the absence of habitual residence is temporary-. At the same time, Stradner (1920, in Fuentes, 2016), tourism is a graph of luxury travelers, that is, of those who leave their habitual residence and go to another place without any economic purpose, but to increase their status and satisfy luxury needs. The Swiss Hunziker and Krapf, (1942, in Viloria, 2012). Likewise, the founders of the humanistic school defined tourism - a set of relationships and phenomena produced by the displacement and temporary stay of people outside their usual place of residence, without being motivated by profit. Magliulo, (2015 in Troisi, 1942) It is conceived as a heterogeneous set of acts of demand and consumption carried out by outsiders in a place of reference, such a set gives rise (or is responded to) by an equally heterogeneous set of goods and services produced in said place. Professor De Arrillaga, (1955, in De la Torre, 1997) tourism is all temporary displacement, determined by causes other than profit; the set of goods, services and organization that in each nation determine and make these trips possible, and the relationships and events that take place between them and the travelers. " (p. 20,21)
At present, it is considered that productive activities in general, as well as projects of any kind, must be granted based on the sustainability approach, and in this, tourism activity is considered, as Ascaino \& Vinicius (2014) define to sustainable tourism as "promoting the sustainable development of tourism that involves the initiative of proposals of small and medium-sized companies can increase the benefits of the resources generated at the local level, maintaining cultural integrity, as well as the protection of natural heritage" ( $\mathrm{p}$. 6).

All the activity developed in the regions, starting from the production of capitalist merchandise, has been, at first, paralyzed, in a second moment, attempts have been made to reactivate it. The reason for this context is due to the pandemic that is experienced in the year 2020; According to the World Health Organization (WHO, 2020) it is defined as "The global spread of a new disease is called a pandemic. An influenza pandemic occurs when a new influenza virus emerges that spreads throughout the world and most people do not have immunity against it" (n/n); However, it is important to differentiate it from the meaning of an epidemic, which in essence is the physical dimension. "For its part, it is classified as an epidemic when a disease spreads actively because the outbreak is out of control and is maintained over time. In this way, the number of cases in a specific geographic area increases. " Polished (2020, p. n/n)

\section{Contextual Framework}

It is important to point out that the subject being addressed is highly circumstantial, therefore, what is exposed here is according to the historical moment in which this writing is prepared, as well as the analysis and reflection of trends; For this case, the topic is contextualized in the months of August and September 2020.

Tourism activity in the world has suffered a setback of exponential magnitudes in this year 2020, which has its root cause in the pandemic spread of the SarsCov-2 coronavirus, which due to its easy-to-spread characteristics and is a new disease for which There is no vaccine, it got out of control and the sanitary fences at the international level could not effectively stop its transmission. 
As of January 13, 2020, when the first case of the coronavirus causing COVID 19 was registered outside of China (in Thailand), the spread of the virus internationally was accelerating, in such a way that in less than two months, on March 11, the World Health Organization (2020) of the United Nations declared the disease a pandemic, when there were affectations in 114 countries, with records of more than 118 thousand cases and a number greater than the four thousand deaths from this virus. In Mexico, starting in mid-March, a policy of decreasing mobility began, thereafter being impacted by tourist activity. Tourism is especially an activity with the characteristic of being very vulnerable to economic, political and social changes, for which the mobility restriction measures significantly affected the country's tourism dynamics in a short term.

The socio-economic dynamics that exist in the world, Mexico and its regions, in general, but at present with a focus on tourism, is framed at a time when there is still no vaccine for the Sars-Cov virus -2 , from the above, the advance in herd immunity, or herd immunization, which is estimated to be reached when $2 / 3$ to $3 / 4$ of the population is immune to a given disease, it is observed very far from reach, since the WHO has indicated, in a conference of its owner, the last week of September, that it is estimated that there is $10 \%$ of the world population that has acquired immunity to the aforementioned virus, which after 10 months Since the emergence of the virus was declared, herd immunity advances at a very slow rate.

The fastest way to achieve herd immunity will be through the application of science and technology to find a vaccine against the aforementioned virus. To this date, some laboratories and countries are in a race to develop the vaccine that allows the world population to resume its pre-pandemic socioeconomic dynamics, in this area, according to INFOBAE (2020), third-class vaccines stand out. phase: Astra Zeneca-Oxford (UK), PfizerBioNtech (EU-Germany), Massachusetts-NHI (EU), Sinovac-Butantan (China-Brazil), State Pharmaceutical China-Wuhan Biological Products Institute (China), Bio -pharmaceuticalChina (China), IISI-University of Melbourne (Australia), plus the two Russian vaccines that are patented but that the WHO has reservations in recognizing them in phase three.
The global significance of the COVID19 pandemic, and the measures that have been taken to address it in favor of public health, have led to a contraction of the world economy in which tourism, one of the The most dynamic and fastest growing sectors on the planet have been one of the most affected. According to data from the International Labor Organization (ILO), this sector generated around 330 million jobs worldwide, for every job created directly by this sector, almost one and a half additional jobs were created indirectly or induced, which which is equivalent to 10.3 percent of total employment; in other words, it employs one in ten people globally. On the other hand, it contributes about $11 \%$ to the world GDP, due to the fact that multiple nations have focused their attention on tourism as a development strategy, but, in addition, it has become the means of integration, empowerment and income generation that brings peoples closer to each other and has even come to be considered as a fundamental pillar for the conservation of the natural and cultural heritage of humanity through sustainability.

According to the World Tourism Organization (UNWTO), the current situation that the planet is going through has led to a cost three times higher than that generated by the global economic-financial crisis that occurred in 2009. Data from the Barometer of the same instance, in the volume 18 (September-August), indicate that the mobility restrictions that were implemented worldwide reduced the arrival of international tourists by $65 \%$ in the first half of the year compared to 2019. This reduction resulted in losses that reached the 460,000 million US dollars, which compared to the 2009 crisis is five times higher. Within this, the region most affected by COVID-19 in tourism has been Asia and the Pacific with a reduction of $72 \%$ in the number of tourist arrivals, Europe in second place with $66 \%$, the Americas with a decrease in $55 \%$, while Africa and the Middle East, both 57\% (UNWTO, 2020). A situation that, without a doubt, has put at risk the livelihoods of millions of people who depend directly or indirectly on tourist activity due to the significant multiplier effect in various sectors, for example, civil aviation, handicrafts, agriculture and food and beverage supplies, and all of these sectors have been deeply affected by the crisis (ILO, 2020). 
The panorama at the national level is not inconsistent with the international situation, tourism in Mexico has been one of the main sources of income in recent decades, its numerous destinations and typologies have positioned it in the first 10 places within the world ranking of arrivals of UNWTO international tourists. Properly, before the pandemic, the national economy had been showing a strong contraction of productive activity and in the presence of the pandemic the situation worsened even more.

In recent years, tourism activity had registered a stable behavior with a positive balance. According to INEGI, from 2010 to 2018 , its contribution to the country's GDP had a minimum of $8.4 \%$ corresponding to 2014 and a maximum of $8.7 \%$ that occurred in 2018 , while in 2019 it had a variation of just $0.3 \%$ compared to 2018 according to the quarterly indicator of tourism GDP, which represents a not very significant growth. It was in the first quarter of 2020 where the decline was evident, in which this indicator registered a decrease of $6.3 \%$ compared to the previous quarter and $5.2 \%$ compared to the same quarter of 2019, so that by July tourism revenues had decreased by $53.89 \%$ compared to the same period of the previous year according to data from Banxico (2020).

There are various scenarios and proposals for the recovery of the sector such as those of Madrid and Díaz (2020) and Santos del Valle (2020), however, in any of the cases, the tourist offer tends towards closer markets, that is, it must prioritize interior tourism, under the assumption that the tourist in this experience of confinement and impediments to mobility has acquired a certain level of social awareness, of connection with the concept of sustainability, and with life itself.

What is a fact, how historically it has happened, is that tourism is related to the discretionary use of people's disposable income. It is clear that travelers are particularly sensitive to taking risks when traveling; On the other hand, tourism has a structural strength based on the fact that travel is part of the lifestyle of current societies, so that when eventual threats to people disappear, it has the ability to quickly reemerge (Díaz, 2020).

\section{Pandemics seen in cycles and waves of contagion}

When observing the behavior of the different pandemics that have hit humanity, there are certain behaviors that tend to repeat themselves; These "waves" of pandemic behavior are variable over time, but what is constant is the period of expansion-stagnation-decline, and again a period of expansion, in the form of cycles.

The only thing that can make the behavior of pandemics similar to the current one not be completely compared is the medical scientific advance that is available now; where at least five vaccines are already in the final stages to be released on the market, this in 10 months after the report of the first case, a race against time never seen before, in terms of being very little time to release a vaccine that generates immunity against the Sars-cov-2 virus.

The Spanish flu is a pandemic that allows a comparison of the aforementioned "waves".

\section{The first wave}

The first wave took place in the spring of 1918. The first detected case was located in a military camp in Kansas, United States. This infection among the troops that had to go to fight in the First World War is called 'herald wave' since it is the one that announced the arrival of the rest. (...)

\section{The second wave}

The second phase of the Spanish flu took place in the fall of 1918. In Spain there are several theories of how it spread. It is believed that it could have been due to the return to their homes in the summer of the soldiers who were doing their military service, or that it had been transported by the Portuguese who were returning by train to their country after the end of the war. It is not ruled out that it was a mutation of the virus. This time, mortality skyrocketed. (...) In the rest of the planet this second wave was also the worst since it was widespread. There is no unanimity on where its focus occurred and there is speculation with Liberia, the North American city of Boston or the French port of Brest. In Australia, which had been saved from the first wave, the arrival of troops from Europe caused 80,000 deaths. (...) 


\section{The third wave}

The Spanish flu would strike again in the first months of 1919, although this time its lethality was, in general terms, lower than in the previous contagion phase. One of the suspicions of the scientists is that the population had already developed sufficient immunity so that the influence of the virus was less. In countries like Japan, for example, the incidence of influenza would last until 1920. When the incidence of the disease ended, in Spain eight million people had already died. (...) The state of science at that time requires that certain data are not available on what happened and why. Viruses, for example, were not known until 1933 so the causes of the disease were a mystery at the beginning of the 20th century. Statistics have established that the virus mainly affected children between one and four years old and young people between 21 and 30 . The place of origin of the virus is unknown, although scientists shuffle the names of three cities: Étaples, in France ; Haskell, in the United States, and Xhanxi, in China. (...)" (Beltrán, 2020)

In this regard, it is noted that, as of September 2020, the American continent is experiencing what seems to be the first wave of infections; Europe and Asia are beginning to experience what they call the second wave, and the mobility of people has even begun to be restricted again; Little is known about Africa, little information circulates; Oceania has not been mentioned regarding the entry of the second wave.

It is in this historical context where Mexico has begun to reactivate its economy and therefore production, more intensely since March 2020. The data on deaths to this date are very controversial, since the official data do not coincide with data from other sources, which indicate an underestimation of deaths from the Covid-19 pandemic. The truth is that daily deaths are added by hundreds, as of today (October 08) the official data is 94,015 deaths from Covid-19; However, the same federal government recognized, days ago, that several thousand Covid-19 tests had been lost, more than 90 thousand, which leaves the possibility that to this day deaths from said disease add up to more than 150 one thousand; as pointed out by many other epidemiological researchers in the country.
"Mexico lost or discarded 93,803 COVID-19 test results during the pandemic, health officials said, reducing already low levels of testing in the country." (Navarro, 2020).

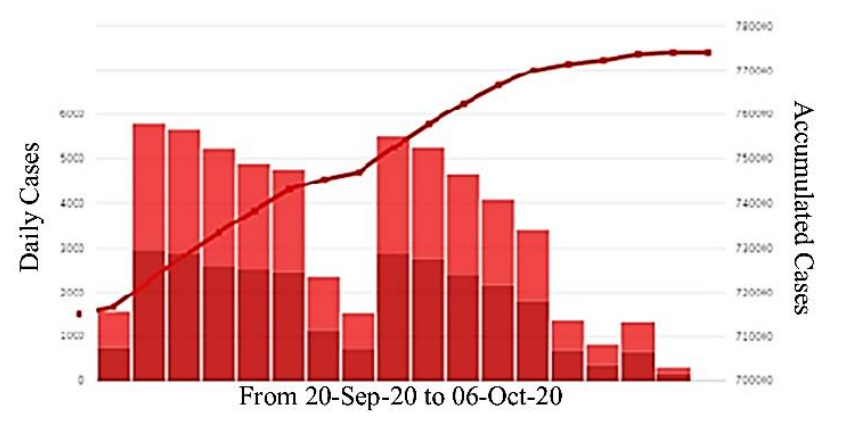

Graphic 1 Confirmed cases of Covid-19 in Mexico, as of October 07, 2020

Source: General Directorate of Epidemiology of the Federal Government of Mexico. (DGE)

Note the behavior of the contagion curve in Mexico, just beginning to experience a stage of stagnation of the period of the first wave of the pandemic. In the future, it will be known how this behavior continued with a process of reactivation of the economy.

\section{Gradual reactivation of tourism}

The World Tourism Organization (2020) launched a technical document to reactivate tourism at the end of May, in which it establishes eight global guidelines, which have been taken up and applied by countries that begin to unfreeze their economic activities.

The first important factor to highlight is that as in all economic activities, the public policies implemented by the countries focus on a gradual reactivation of activities, and a fundamental factor is the commitment mainly to domestic tourism since there is still a The vast majority of countries continue with restriction measures, especially for non-essential travel, including travel for leisure purposes.

Policies then focus on encouraging consumption by domestic tourism, and in which mobility of short distances stand out, this phenomenon also responds to tourist demand, projections of reactivation indicate that potential tourists will choose to take short trips, and even excursions to and from nearby destinations, due to the obvious risk involved in traveling even after the restriction measures are lifted. 
Public policies for economic reactivation in tourism are beginning with transportation and accommodation, gradually removing restrictions from the source markets in the case of the countries that so determined, and reactivating a greater number of flights, in the case of the lodging, the hotel industry is reactivated with a capacity limit; After transportation and lodging, which are the basis for tourist consumption and the possibility of travel, they begin to reactivate spaces for tourist use, mainly food and beverage services, beaches, shopping centers and public squares, and finally tourist centers. entertainment (mainly cafes, bars and the like), still excluding spaces such as museums, events and convention centers, as well as services for tourist tours, theme parks and common areas of hotels.

\section{Limitation of tourist carrying capacity}

The second aspect that takes great importance, and that apparently is the spearhead that will determine the development of tourist activities during the reactivation of this activity is the tourist load capacity, all tourist destinations of great importance and high concentration of tourists are defining maximum visitor reception capacities per day, and by area or attraction visited.

Tourist carrying capacity is a concept that has been used for some years, mainly related to the use of natural resources for tourist use, so the meanings are concentrated on the impact on tourist spaces; Among the main definitions in this regard are those of Mathieson and Wall (1990), and that of O 'Rally (1986, cited by Echamendi Lorente, 2001), which focus on the number of tourists who can visit a certain tourist attraction without a considerable alteration to the physical environment is generated and without this diminishing the quality of the tourist experience of the visitors.

Although the main concepts focus on the environmental part, it is true that the carrying capacity must consider the social and economic aspects that are generated in said tourist attraction, in such a way that it has been a fundamental aspect for the planning of sustainable tourism.
Therefore, the tourist carrying capacity has the purpose of preserving over time the possibility of continuing to make tourist use of the attractions, while ensuring their preservation and the environmental, ecosystem and social conditions involved, in addition to generating an economic benefit for the host communities.

The new normality of tourism, then contemplates establishing visitor limits both in tourist areas and in service establishments; However, a notable difference is that the tourist carrying capacity is not defined taking into account environmental aspects as is the main purpose of the proposed methodologies, among the most used is that of Cifuentes (1992); Rather, they focus on health aspects clearly, establishing limits to avoid possible infections, thinking about the number of people who can use the same space with an adequate distance between them to minimize the risks of contagion.

The limitation of load capacity will pose a challenge for mainly sun and beach tourist destinations, as well as those of overcrowding, since they will continue to be the main destinations chosen by tourist demand, an example of this is in China, where in the first long weekend of May 1, its main tourist destinations had a greater influx than expected, generating conglomerations.

\section{Partial or total restrictions on source markets}

As one of the central policies continues to be the restriction of mobility as far as possible, and an important policy for the tourism sector that different countries have championed is the restriction of specific source markets, this occurs in two ways: limiting the flow of travelers from the decrease in communication (transport) and the total restriction when completely canceling transport with certain countries (issuing markets) or even closing the borders partially or totally.

This policy has been applied in the vast majority of countries, mainly through the restriction of transport, mainly the decrease in flights, however, these policies have been applied more intensely in the countries of the European Union such as Italy and Spain, to a lesser extent also applied by the United Kingdom, Germany, France and the Netherlands among others; It has also been applied in Asian countries, mainly China and Japan. 
The restriction with issuing markets has also been applied internally in the countries, mainly by restricting non-essential travel, placing sanitary filters and even closing specific cities, where filters have been established that prevent entry without reason. weight to arriving travelers.

\section{Adaptation of tourist activities and services}

Finally, the fourth guideline of public policies for the reactivation of tourism is the adaptation and regulation for the practice of tourist activities and the provision of services.

As restriction measures, the determination of the determined capacity in a tourist space has been intensified, delimiting the capacity of accommodation, food and beverage establishments, and even public spaces such as beaches, parks, squares, shopping centers, among others, in addition to the restriction of opening to specific tourist services businesses such as sea tours, hiking, and even complementary urban services, all with the aim of discouraging the displacement and concentration of tourists, mainly in those destinations with high demand.

For the practice of tourist activities and the provision of services, different protocol proposals have also been established, in which preventive measures are established in the development of activities, among which the reduction of the capacity of establishments, especially closed spaces, stands out. In food and beverage establishments, for example, it is established to remove tables and leave them at a greater distance, in addition to not having tables with more than 6 people. In the practice of tourist activities such as the enjoyment of beaches, a limit of visitors to each beach has been established, in addition to social distancing practices, avoiding groups and commerce on public beaches.

For tourist tour services, reductions have been established in the number of people that make up a group and practice all hygiene measures during tours, the mandatory use of face masks by service providers and users, among others.
For now, at the beginning of the reactivation, the operation of spas, sea tours, bars and entertainment establishments, including the opening of museums, galleries and the like, has been left out in general.

The transport services are also adapting their transfer practice, in addition to adapting all hygiene measures, they are implementing a reduction in the maximum capacity allocated per unit, in such a way that they can have larger spaces between users and thus maintain a safe distance; this specific measure is contemplated on a temporary basis, mainly due to the operating costs involved.

The attributes of the tourist destinations will have to be rethought to adapt to the new characteristics of use of the space, the message that will have to be part of the current scenarios and will have to generate awareness about the general complications of carrying out tourist activity based on the contagion characteristics of the virus, so that the relationship with tourists is adapted to the circumstances and the communication channels are focused on a distribution of information that prevents the risk of contact between users, host locations and service providers. This process of reactivation of tourist activity, like the economy in general, is that in no region, be it tourist or industrial, is designed for economic paralysis, the economic system requires production to generate the circulation of capital and the benefit of the region and its population.

In order to specifically visualize in practice, the implementation of these four guidelines to carry out the reactivation of tourism at the international level, below are presented four specific examples of countries that have been among the first to start the reactivation, since its planning until the implementation of the first actions, these countries are China, the origin of the virus, and the first countries with reactivation, Italy, the first European country seriously impacted by the pandemic and that has begun a process of gradual reactivation, Spain, which is one of the countries with the greatest tourist relevance in the world, and which also went through a health crisis as it was even overwhelmed with respect to its capacity for care in hospitals, has also begun its reactivation, although less rapidly than Italy, and is dependent mainly from foreign tourism. 
Finally the United States is analyzed in the American continent, as it is the first country in the continent that presented an accelerated contagion, with a problem of attention in the health systems in an important way, but that has decided to reactivate its economic activities, including tourism, more quickly.

Finally, the case of Mexico is presented, with the first advances in the reactivation of tourism, for which we present its main strategies.

\section{Tourist reactivation strategies in some countries with relevant tourist activity China}

In the month of April China begins to reactivate its economy, after the first half of the month it is when it begins to remove the restrictions on tourist mobility and internal tourism is gradually reactivated, for this a series of measures are taken for the mobility, including limiting the tourist influx in destinations and establishments of tourist and complementary services, limiting the load capacity, in the case of accommodation and food and beverage establishments the maximum capacity should be $30 \%$, and only began to open around 70\% of the country's tourist attractions (Xhinua español, 2020).

During the bridge on the first of May there was an important record of trips, according to what was reported by China Tourism Academy (2020, cited by El Confidencial, 2020), as part of the gradual reactivation, the use of face masks was established in Mandatory public spaces, the restriction was to limit up to $30 \%$ the influx of visitors in main destinations, for establishments and closed sites this occupation should be at a maximum of $50 \%$ capacity, depending on the size of the space.

Regarding the limitation of emerging markets, the main airlines such as United Airlines, Delta Air Lines, Lufthansa, Air France, British Airways and Virgin Atlantic suspended flights to China, some even remain restricted from certain source markets where contagion levels remain high, with this, what is sought is to minimize the risk of a rebound in the epidemic, its borders have also been partially closed to reduce mobility between neighboring countries (Vidal Liy, 2020).
As an adaptation of activities, the reactivation policies focused on shorter visits, limiting visiting hours, and above all, concentration of tourists in specific spaces, this also based on a measure of visits in staggered hours, applied in the main destinations in such a way that there could be a time difference between groups visiting the tourist attractions.

The practice of public policies did not prevent agglomerations from occurring in some tourist destinations in the country, showing that it is not easy to establish visitor limits in the tourist destinations with the highest demand, it also shows that the recovery of the tourism sector can be much more accelerated than what is projected, in a single long weekend, the first for China after the mobility restriction policies, travel recovered by 59\% compared to the same period of the previous year, and the reduction of tourism income It was around 9 billion dollars (El confidential, 2020), however, a significant recovery is perceived in a very short time.

\section{Italy}

Italy, the first country in the European Union that had problems controlling and mitigating the effects of the pandemic, became the epicenter of infections once China began the decline in its epidemiological curve, in this country, there was a mandatory quarantine with coercive measures to avoid mobility as much as possible; Once the critical period had passed, but with a still high rate of infections and hospitalizations, the country began with a gradual reactivation of its economy and it is towards the end of May that mobility restrictions are lifted in the country and They resume their daily activities with a series of prevention measures, as in China, in addition to this, they begin to plan communications for mobility between European countries where contagion levels are lower, thinking of reactivating foreign tourism.

As measures of gradual reactivation, at the beginning of June the internal borders were released, allowing mobility throughout the country without special permission, as well as the reopening of the borders to foreign tourism with the countries of the European Union only, for this they were established also prevention protocols in airports, together with those of operation for tourist services. 
For this, the capacity in transport services was limited, ensuring social distancing, as well as ensuring that service establishments only have the capacity that allows them to guarantee a minimum space of 1 square meter per user, sanitization of areas and beaches, as well such as establishing a minimum space of $10 \mathrm{~m}^{2}$ for each installed umbrella, also prohibiting group recreational and recreational activities, as well as tourist routes such as adaptation of tourist activities, there is also no buffet service, and the common areas of hotels must establish capacity limit according to the available space (Agenzia Nazionale Turismo, 2020). The advantages of applying these measures is not to generate a contagious situation that once again paralyzes tourist activity, as already mentioned, when preventing the mobility of people, tourism is one of the main affected.

To encourage domestic tourism as a strategy for gradual reactivation, the country established a series of fiscal incentives for tourists who decided to travel, with an investment of more than four billion euros, in their attempt to rescue this economic activity that represents more than $13 \%$ of its GDP (El mundo, 2020), in addition to this, on June 3 the country decides to open its borders to the European Union and encourage international travel in its main issuing markets, mainly with Germany, this gradually and controlled with a limited number of flights initially, communication with source markets in the Americas, Asia, Africa and Oceania continues to be restricted.

\section{Spain}

Spain is one of the countries that has also been badly hit by the virus, between the months of March and April it had its highest number of infections, reaching a health crisis to address this problem, in this country, restriction measures to mobility has been longer and confinement extended until June, the month in which a gradual reactivation of its economy also begins; However, tourism does not enter this first phase of reactivation, not even for domestic tourism, it is until June 21 that mobility locks are removed, with prevention measures throughout the country (El País, 2020)
The tourism reactivation plans have been programmed for the month of July; Even so, there are restrictions on the arrival of foreign tourists by imposing a mandatory 14-day quarantine on all foreigners who arrive in the country, which discourages the flow of international tourists, so efforts are focused on activating tourism domestic, this as a measure of restriction of issuing markets, although it is a great inconvenience as it is close to the summer holidays, one of the most important periods of high season in the country, where foreign tourism is the main tourist dynamic in this period, Therefore, work is currently being done to plan the tourist reactivation to open the borders to the European Union, mainly its main markets: England, France and Germany (Cerdeira, 2020).

As an adaptation of the tourist activities and services, the sanitization of spaces used by users in establishments has been arranged, guaranteeing social distancing between service providers and users, and cleaning and disinfection programs have also been carried out, both in areas for public use such as rooms, food and sanitary service tables, cleaning and hygiene supplies in all public areas, and sanitary filters at entrances to food and beverage establishments and other tourist services (Ministry of Industry, Commerce and Tourism, 2020).

As measures of restriction to load capacity, hotels will operate at a maximum of $50 \%$ of their capacity, and all establishment of tourist or complementary services will have a capacity limitation with the restriction of capacity to a maximum of 4 people for each $10 \mathrm{~m}^{2}$, cruises are still canceled in the country, and tourist routes can be practiced ensuring measures of social distancing from transport, so the size of the groups will have to be reduced.

As in the previous examples, in Spain all efforts are focused on reactivating domestic tourism, hoping that with this there will be a mobility of at least 4 million tourists for the summer, which is still far from the 30 million tourists received. in the same period last year. 


\section{United States}

The United States was the first country in the American continent where the rate of infections increased rapidly, the first record of a case of COVID 19 occurred in January, but no restriction measures were taken until the middle of the month of February, when flights from China were initially restricted, a few weeks later the mobility of 26 European countries was restricted; However, mitigation measures were not enough and by March 26 the United States became the epicenter of the epidemic, displacing China and Italy, which were in the first two positions (El País, 2020)

For the economic reactivation, a threephase plan was designed (CNN, 2020), which allows starting from the second phase to carry out tourist activities, said reactivation plan, however, could be activated and carried out in accordance with the decisions and considerations of each state, so that such implementation would vary according to development in each entity.

After a slowdown in the rate of infections during the month of May, the economic reactivation, including that of travel and tourism, resulted in a second wave of infections that caused its epidemic curve to resume an accelerated rate of contagion that began In midJune, and which has been maintained throughout the month of July, the daily accumulated of cases is even greater than that of the first wave.

Regarding the reactivation policies for tourism, the country decided not to limit internal mobility to the minimum, but rather to reduce the supply of transport services, limiting the number of flights and connections; however, ground transportation was not restricted (especially mobility by private car); This decrease in mobility has been gradually withdrawn, to date, the number of flights and connections has not recovered, but there is already greater mobility in air transport, foreign travel restrictions are maintained, retaking some connections and beginning to increase the frequency of flights (US. Travel Association, 2020).
To maintain adequate social distancing, according to documents published by the United States Travel Association (2020), a reduction in capacity has been arranged in all types of tourist service establishments, reducing the number of workers and users in hotels to guarantee an adequate distance, this also applies to food and beverage establishments, bars and places of entertainment and tourist routes; It has also been requested, as measures of adaptation of activities, that transactions that require physical contact between service providers and users be reduced, using other types of methods for payment transactions, reservations, registration of entries and exits, even in entertainment services and amenities, putting physical containment barriers between people as transparent modules for communication between service providers and users.

\section{Mexico}

In Mexico, a regionalization of the territory was developed to define the levels of contagion in each of the states, and to be able to decide in a different way, the activities that have to be reactivated in each entity, in this sense, a semaphore of weekly evaluation that indicates the economic activities that can be resumed composed of four colors, red, orange, yellow and green; tourism can begin to reactivate with an orange traffic light, with $25 \%$ occupancy, the reactivation was planned for June 1 , however due to the behavior of contagions, this has been going through, and finally the opening is given from On July 1, tourist activity began to reactivate in the main tourist destinations of the country, with a series of preventive measures in which activities in common areas of the accommodation establishments are restricted, as well as a maximum capacity of $25 \%$ in spaces tourists and maintaining a safe distance between visitors.

As shown by the examples presented, gradual reactivation is one of the main strategies to resume tourism activities. The objective is to move forward in reopening, avoiding the risks of contagion re-emergence, as this would discourage travel motivation. 
However, from a commercial perspective, the gradual reopening is also due to the demand for tourist services, since the potential demand is also limited, it is not yet in the collective interest to resume travel activities for leisure and recreation, due to the risk that it still means leaving their places of origin, especially to destinations abroad.

The limitation of the load capacity is the second important factor detected as part of the public policies applied in the countries, in the case of Mexico, it has been determined to operate initially with $25 \%$ capacity in lodging establishments, thus such as beaches, squares, markets and shopping centers, and not initially operating water tours and tourist routes, nor the opening of parks or spas, nor bars or entertainment centers.

Once a yellow traffic light phase is advanced, open public spaces may be used with normal capacity, maintaining hygiene and prevention measures, the operation of bars and entertainment centers, as well as closed spaces may operate with limited capacity, In this phase, the reopening of all economic activities begins, including events and meetings with controlled capacity, and the limitation of the load capacity will be increasingly deregulated until the last phase of reactivation of the green traffic light.

Regarding the policies of restriction of issuing markets, the country did not apply a specific restriction to any issuing market, however all tourism activity was stopped in $100 \%$ of the country's destinations, so that no tourist service establishment could operate and With this, the operation was restricted to every possible issuing market. Currently, Mexico is beginning a promotion strategy to encourage tourism in its main markets, but mainly addressing the promotion of domestic tourism.

\section{Conclusions}

The results presented confirm the existence of four general guidelines implemented in public policies for the economic reactivation of tourism at the international level, necessary to be able to reactivate activities with the necessary prevention to reduce the risk of infection and spread of the virus.
The purpose, therefore, of these four guidelines in public policies are aimed at gaining the confidence of the issuing markets about the safety that exists in tourist destinations for their use and enjoyment.

According to what has been stated in terms of phases and waves, the reactivation of the tourism sector may not be $100 \%$ in the short and possibly medium term; since, to achieve a normal reopening, it should be based on herd immunity at the international level; which can be obtained as the world population becomes infected and exceeds it, or through mass vaccination. In both cases, the expectation is that it will take a few years to achieve this. In the event that it is due to vaccination, which is most likely, it is considered until 2023 to already have an important coverage of the population with access to the vaccine.

Derived from all the exposed in the present document, it can be observed, a great possibility; that the tourism industry, and other branches of the economy, have to adapt to having a lower rate of profit than that normally obtained in the pre-Covid-19 pandemic. For the insertion of the tourism industry in the current historical economic-epidemiological context.

In order to effectively promote the accelerated reactivation of the tourist dynamics, it is also necessary to migrate the vast majority of transactions to the virtual market, from the offer of services, to collection transactions, cancellations, changes and refunds, this trend has been markedly necessary, based on the restrictions in economic activities and transactions since this communication and transaction system was required to make cancellations or date changes in transportation services, reservations in lodging establishments, cancellation of tours and tourist packages, and even the cancellation or change of date of social events, congresses and conventions that were already scheduled, for which it was strictly necessary to be able to solve these problems mainly through electronic means. 


\section{References}

Agenzia Nazionale Turismo. (Mayo de 2020). Directrices para la reapertura de las actividades económicas y productivas. Italia. Recuperado el 28 de junio de 2020, de http://www.italia.it/es/informacionutil/directrices-para-la-reapertura-de-lasactividades-economicas-y-productivas.html

Agenzia Nazionale Turismo. (Mayo de 2020). Directrices para la reapertura de las actividades económicas y productivas. Italia. Recuperado el 28 de junio de 2020, de http://www.italia.it/es/informacionutil/directrices-para-la-reapertura-de-lasactividades-economicas-y-productivas.html

Antonio Santos del Valle (2020), La industria turística y el impacto del Covid-19 escenarios y propuestas, Global Journey Consulting,

Ascaino, Alfredo \& Vinicius, Marcus (2014). Turismo sustentable, el equilibrio necesario en el siglo XXI. Edit. Trillas. México.

Banxico (2020), Sistema de Información Económica/ Viajeros Internacionales. Disponible en https://www.banxico.org.mx/SieInternet/consult arDirectorioInternetAction.do?sector=1\&accion $=$ consultarCuadroAnalitico\&idCuadro=CA198 \&locale $=$ es

Beltrán, Oscar (2020). Así fueron las tres oleadas de la gripe española: un virus mortal. Edit. Historia del Sur. España. Url: https://www.diariosur.es/sur-historia/segundaoleada-gripe-20200704192755-

nt.html?ref=https:\%2F\%2Fwww.diariosur.es\% 2Fsur-historia\%2Fsegunda-oleada-gripe20200704192755-nt.html

BRC (2020). Reactivación económica. Edit. RCBRC. Colombia.

Camelo, Octavio \& Rodríguez, Juan (2018). Why tequila is named tequila? An approach from the regional economic history. V-9:N-20, P. 15-28. Edit. Journal Ecorfan. México

Camelo, Octavio (2014). El impacto del crecimiento y desarrollo económico en el proceso de urbanización, Caso.- Municipio de Bahía de Banderas, Nayarit. Edit. UNAM. México.
Camelo, Octavio. Rodríguez, Eusebio \& Rodríguez, Nely (2020). Turism and regional development as an expression of the globalization. Case.- Mexico-Cuba. Edit. Ecorfan. España.

Cerdeira, L. (02 de Julio de 2020). Así se prepara España para reactivar el turismo. Forbes. Recuperado el 16 de Julio de 2020, de https://forbes.es/empresas/71039/asi-seprepara-espana-para-reactivar-el-turismo/

Cerdeira, L. (02 de Julio de 2020). Así se prepara España para reactivar el turismo. Forbes. Recuperado el 16 de Julio de 2020, de https://forbes.es/empresas/71039/asi-seprepara-espana-para-reactivar-el-turismo/

Cifuentes, M. (1992). Determinación de capacidad de carga turística en áreas protegidas. Centro agronómico tropical de investigación y enseñanza Catie, Turrialba, Costa Rica.

Cifuentes, M. (1992). Determinación de capacidad de carga turística en áreas protegidas. Centro agronómico tropical de investigación y enseñanza Catie, Turrialba, Costa Rica.

CNN. (17 de Abril de 2020). En detalle: las tres fases del plan de Donald Trump para "reabrir Estados Unidos". Recuperado el 16 de Mayo de 2020, de https://cnnespanol.cnn.com/2020/04/17/las-tresfases-del-plan-de-donald-trump-para-reabrirestados-unidos-otra-vez/

CNN. (17 de abril de 2020). En detalle: las tres fases del plan de Donald Trump para "reabrir Estados Unidos". Recuperado el 16 de mayo de 2020,

https://cnnespanol.cnn.com/2020/04/17/las-tresfases-del-plan-de-donald-trump-para-reabrirestados-unidos-otra-vez/

De la Torre, P. O. (1997). El turismo. Fenómeno social. $2^{\mathrm{a}}$ Ed. México, D. F.

DGE (07-oct-2020). Covid-19 México, información general. Edit. Gobierno de México. Url: https://coronavirus.gob.mx/datos/

Echamendi Lorente, P. (2001). La capacidad de carga turística. Aspectos conceptuales y normas de aplicación. Anales de grografía de la Universidad Complutense, 11- 30. 
Echamendi Lorente, P. (2001). La capacidad de carga turística. Aspectos conceptuales y normas de aplicación. Anales de geografía de la Universidad Complutense, 11- 30.

El confidencial. (07 de mayo de 2020). ¿Una L, una $\mathrm{U}$ o una V? China muestra el camino de cómo reactivar el consumo. España. Recuperado el 19 de mayo de 2020, de https://www.elconfidencial.com/mundo/202005-07/china-economia-coronavirus-comoreactivar-consumo_2582328/

El confidencial. (07 de mayo de 2020). ¿Una L, una $\mathrm{U}$ o una V? China muestra el camino de cómo reactivar el consumo. España. Recuperado el 19 de mayo de 2020, de https://www.elconfidencial.com/mundo/202005-07/china-economia-coronavirus-comoreactivar-consumo_2582328/

El mundo. (15 de mayo de 2020). Italia busca reactivar el turismo interior con incentivos fiscales de hasta 500 euros a las familias para las vacaciones. Italia. Recuperado el mayo de 19 de 2020,

https://www.elmundo.es/economia/ahorro-yconsumo/2020/05/15/5ebe2c25fdddfff4bb8b45 c1.html

El mundo. (15 de mayo de 2020). Italia busca reactivar el turismo interior con incentivos fiscales de hasta 500 euros a las familias para las vacaciones. Italia. Recuperado el mayo de 19 de 2020,

https://www.elmundo.es/economia/ahorro-yconsumo/2020/05/15/5ebe2c25fdddfff4bb8b45 c1.html

El país. (04 de junio de 2020). España se queda a la cola en la reactivación del turismo en Europa. Madris, España. Recuperado el 25 de junio de 2020, de https://cincodias.elpais.com/cincodias/2020/06/ 03/companias/1591197937_202826.html

El país. (04 de junio de 2020). España se queda a la cola en la reactivación del turismo en Europa. Madrid, España. Recuperado el 25 de junio de 2020, de https:/cincodias.elpais.com/cincodias/2020/06/ 03/companias/1591197937_202826.html
El país. (27 de marzo de 2020). Estados Unidos se convierte en el nuevo epicentro de la pandemia del COVID-19. Recuperado el 19 de mayo de 2020, de https://www.elpais.com.uy/mundo/estadosunidos-convierte-nuevo-epicentro-pandemiacovid.html

El País. (27 de Marzo de 2020). Estados Unidos se convierte en el nuevo epicentro de la pandemia del COVID-19. Recuperado el 16 de mayo de 2020, de https://www.elpais.com.uy/mundo/estadosunidos-convierte-nuevo-epicentro-pandemiacovid.html

El país. (27 de marzo de 2020). Estados Unidos se convierte en el nuevo epicentro de la pandemia del COVID-19. Recuperado el 19 de mayo de 2020, de https://www.elpais.com.uy/mundo/estadosunidos-convierte-nuevo-epicentro-pandemiacovid.html

El País. (27 de marzo de 2020). Estados Unidos se convierte en el nuevo epicentro de la pandemia del COVID-19. Recuperado el 16 de mayo de 2020, de https://www.elpais.com.uy/mundo/estadosunidos-convierte-nuevo-epicentro-pandemiacovid.html

Francisco Madrid y José Ángel Díaz Rebolledo (2020), Coronavirus y turismo, documento 06, CICCTUR

Heiler, W. (1970 [1937]). Diccionario de economía política. Edit. Labor. España.

INEGI (2020), PIB y cuentas nacionales/indicadores

macroeconómicos/indicador trimestral de la actividad turística. Disponible en: https://www.inegi.org.mx/temas/itat/

INFOBAE (2020). Covid-19, ¿cuáles son las 7 vacunas más avanzadas?. Url: https://www.infobae.com/america/tendenciasamerica/2020/08/04/covid-19-cuales-son-las-7vacunas-mas-avanzadas-quienes-las-hacen-yen-que-estado-se-encuentran/

Mathieson, A., \& Wall, G. (1990). Turismo, repercusiones económicas, físicas y sociales. Trillas. México. 
Mathieson, A., \& Wall, G. (1990). TURISMO. REPERCUSIONES ECONOMICAS, FISICAS Y SOCIALES. Trillas.

Ministerio de Industria, Comercio y Turismo. (11 de Marzo de 2020). Turismo lanza una Guía de buenas prácticas para los establecimientos y los trabajadores del sector turístico. Recuperado el 16 de Mayo de 2020, de https://turismo.gob.es/es-

es/Novedades/Documents/Gu\%C3\%ADa\%20d e\%20Buenas\%20Pr\%C3\%A1cticas\%20COVID 19.pdf

Ministerio de Industria, Comercio y Turismo. (11 de marzo de 2020). Turismo lanza una Guía de buenas prácticas para los establecimientos y los trabajadores del sector turístico. Recuperado el 16 de mayo de 2020, de https://turismo.gob.es/es-

es/Novedades/Documents/Gu\%C3\%ADa\%20d e\%20Buenas\%20Pr\%C3\%A1cticas\%20COVID 19.pdf

Navarro, Andrea (2020). México reconoce que perdió 93,803 resultados de pruebas de Covid19. Periódico: El Financiero (30-09-20): Url: https://www.elfinanciero.com.mx/nacional/mex ico-reconoce-que-perdio-93-803-resultados-depruebas-covid-19

OMC (2020). ¿Qué es una pandemia?. Edit. OMS. Url: https://www.who.int/csr/disease/swineflu/frequ ently_asked_questions/pandemic/es/

Organización Internacional del Trabajo (2020), El impacto de la COVID-19 en el sector del turismo, nota informativa.

Organización Mundial del Turismo. (2020). Directrices globales de la OMT para reiniciar el turismo. Madrid, España: Orgnización Mundial del Turismo. Recuperado el 02 de junio de 2020, de https://webunwto.s3.eu-west1.amazonaws.com/s3fs-public/202006/200606\%20-

\%20UNWTO\%20Global\%20Guidelines\%20to \%20Restart\%20Tourism\%20ES.pdf
Organización Mundial del Turismo. (2020). Directrices globales de la OMT para reiniciar el turismo. Madrid, España: Organización Mundial del Turismo. Recuperado el 02 de junio de 2020, de https://webunwto.s3.eu-west1.amazonaws.com/s3fs-public/202006/200606\%20-

\%20UNWTO\%20Global\%20Guidelines\%20to \%20Restart\%20Tourism\%20ES.pdf

Organización Mundial del Turismo. (28 de Abril de 2020). El 100\% de los destinos del mundo ha restringido ya los viajes a causa de la covid-19, informa la OMT. Recuperado el 18 de Mayo de 2020, de https://www.unwto.org/es/news/covid19-restricciones-viajes

Organización Mundial del Turismo. (28 de abril de 2020). El 100\% de los destinos del mundo ha restringido ya los viajes a causa de la Covid-19, informa la OMT. Recuperado el 18 de mayo de 2020, de https://www.unwto.org/es/news/covid19-restricciones-viajes

Pulido, Sandra (2020). ¿Cuál es la diferencia entre brote, epidemia y pandemia?. En: Gaceta médica. Marzo $12 . \quad$ Url: https://gacetamedica.com/investigacion/cual-esla-diferencia-entre-brote-epidemia-ypandemia/\#: : :text=Por $\% 20$ su $\% 20$ parte $\% 2 \mathrm{C} \% 2$ 0se $\% 20$ cataloga,en\%20una $\% 20 \%$ C3\%A1rea\% 20 geogr $\% \mathrm{C} 3 \% \mathrm{~A} 1$ fica $\% 20$ concreta.

Sandoval, Luis. (2008). Los ciclos largos de la coyuntura económica. Edit. UNAM. México.

US. Travel Association. (2020). Emergency Preparedness and Response: Coronavirus (COVID-19). Recuperado el 16 de julio de 2020

US. Travel Association. (2020). Emergency Preparedness and Response: Coronavirus (COVID-19). Recuperado el 16 de julio de 2020

US. Travel Association. (2020). Industry Guidance for Promoting the Health and Safety of All Travelers. Recuperado el 24 de Junio de 2020, de https://www.ustravel.org/toolkit/industryguidance-promoting-health-and-safety-alltravelers 
US. Travel Association. (2020). Industry Guidance for Promoting the Health and Safety of All Travelers. Recuperado el 24 de junio de 2020 ,

https://www.ustravel.org/toolkit/industry-

guidance-promoting-health-and-safety-all-

travelers

Vidal Liy, M. (26 de marzo de 2020). China cierra sus fronteras a la mayoría de los extranjeros por el coronavirus. El País. Recuperado el 28 de junio de 2020, de https://elpais.com/sociedad/2020-03-26/chinacierra-sus-fronteras-a-los-extranjeros-por-elcoronavirus.html

Vidal Liy, M. (26 de marzo de 2020). China cierra sus fronteras a la mayoría de los extranjeros por el coronavirus. El País. Recuperado el 28 de junio de 2020, de https://elpais.com/sociedad/2020-03-26/chinacierra-sus-fronteras-a-los-extranjeros-por-elcoronavirus.html

Villa, José Luis. (2003). Tesis: Propuesta de criterios para una política de desarrollo social regional para el estado de Colima. Edit. Universidad de Colima. México.

World Tourism Barometer Volume 18, Issue 5, August/september 2020 disponible en https://www.e-

unwto.org/doi/epdf/10.18111/wtobarometereng. 2020.18.1.5

Xhinua español. (04 de abril de 2020). China toma medidas para abordar riesgos de epidemia en sitios turísticos. Beijing, China

Xhinua español. (04 de abril de 2020). China toma medidas para abordar riesgos de epidemia en sitios turísticos. Beijing, China. 